\title{
Study on the Mechanism of Organic Matter Enrichment in Early Cambrian Marine Shales in the Lower Yangtze Area, South China: An Example Using Well JXY1
}

\author{
Sihong Cheng, ${ }^{1,2,3}$ Bin Li $\mathbb{D}^{4,5}$ Kun Zhang $\mathbb{D}^{4,6}$ Weiwei Liu, ${ }^{3}$ Jun Peng, ${ }^{4,6}$ Mingcai Hou, ${ }^{1,2}$ \\ Ming Wen, ${ }^{7,8}$ Qingsong Xia, ${ }^{4,6}$ Xin Wang, ${ }^{7,8}$ Xiaoxue Liu, ${ }^{7,8}$ Li Zhong,,6 Yizhou Huang, \\ Yongyang Liu, ${ }^{4,6}$ Muhe Yuan, ${ }^{4,6}$ and Yue Yao ${ }^{4,6}$ \\ ${ }^{1}$ Institute of Sedimentary Geology, Chengdu University of Technology, Chengdu 610059, China \\ ${ }^{2}$ State Key Laboratory of Oil and Gas Reservoir Geology and Exploitation, Chengdu University of Technology, \\ Chengdu 610059, China \\ ${ }^{3}$ Jiangxi Provincial Shale Gas Investment Company, Ltd., Nanchang 330000, China \\ ${ }^{4}$ School of Geoscience and Technology, Southwest Petroleum University, Chengdu 610500, China \\ ${ }^{5}$ State Key Laboratory of Shale Oil and Gas Enrichment Mechanisms and Effective Development, SINOPEC, Wuxi 214162, China \\ ${ }^{6}$ State Key Laboratory of Oil and Gas Reservoir Geology and Exploitation, Southwest Petroleum University, Chengdu 610500, China \\ ${ }^{7}$ State Key Laboratory of Petroleum Resources and Prospecting, China University of Petroleum, Beijing 102249, China \\ ${ }^{8}$ Unconventional Natural Gas Institute, China University of Petroleum, Beijing 102249, China \\ ${ }^{9}$ Organic Geochemistry Unit, School of Chemistry, University of Bristol, Cantock's Close, Bristol BS8 1TS, UK
}

Correspondence should be addressed to Bin Li; libinxnsy@outlook.com and Kun Zhang; shandongzhangkun@126.com

Received 24 December 2019; Revised 8 July 2020; Accepted 14 July 2020; Published 25 August 2020

Academic Editor: Ling-Li Zhou

Copyright ( $) 2020$ Sihong Cheng et al. This is an open access article distributed under the Creative Commons Attribution License, which permits unrestricted use, distribution, and reproduction in any medium, provided the original work is properly cited.

\footnotetext{
The abundance of organic matter in shales, which has a direct effect on the hydrocarbon generation potential of shales, is an important organic geochemical parameter for evaluating shale gas reservoirs. The total organic carbon content (TOC content) in shale is controlled by the abundance of original sedimentary organic matter. Therefore, it is very important to study the mechanism of organic matter enrichment in shale. In this paper, the Lower Cambrian marine shales from the Lower Yangtze region are selected as the research subject, most of which originate from a typical area well called Well JXY1. The degree of pyritization (DOP) is used to characterize the redox environment of the water body, while the P/Al ratio is used to analyze the biological productivity of paleoseawater. The paleosalinity of seawater is calculated via carbon and oxygen isotope analysis. In addition, the early Cambrian hydrothermal activities were studied by using core description; $\mathrm{Si}$, Al, $\mathrm{Fe}$, and $\mathrm{Mn}$ elemental analysis; and oxygen isotope calculations. The results show that during the early Cambrian Wangyinpu sedimentary period, the seawater was an anaerobic water body with $\mathrm{H}_{2} \mathrm{~S}$, and the oxygen concentration was approximately $0 \mathrm{~mL} / \mathrm{L}$. In the middle stages of the Wangyinpu sedimentary period, the water body had the strongest reducibility and the highest biological productivity. Moreover, the paleoocean in this period between the Yangtze plate and the Cathaysian plate was greatly affected by hydrothermal activities, with temperatures ranging from $90^{\circ} \mathrm{C}$ to $120^{\circ} \mathrm{C}$. Active hydrothermal activities promoted high biological productivity and an anaerobic environment, both of which were conducive to the preservation and enrichment of organic matter, resulting in extremely high TOC content in the Wangyinpu shales (from $6.5 \%$ to approximately $16 \%)$.
} 


\section{Introduction}

As targets of geological explorations of oil and gas change from conventional reservoirs to unconventional reservoirs, the exploration and development of unconventional oil and gas (including shale gas, shale oil, and tight gas) have achieved great success in North America, and this makes the United States essentially self-sufficient in oil and gas, thus achieving "energy independence" [1-6]. There are also unconventional oil and gas resources with great potential in South China, among which are two sets of marine shales, the Upper Ordovician-Lower Silurian shales and the Lower Cambrian shales, which are the main exploration target series. Since 2010, in reference to shale gas exploration and development experience and to technology, China's oil companies have successively implemented commercial development in Weiyuan, Changning, Zhaotong, Luzhou, Yongchuan, Jiaoshiba, Dingshan, and other shale blocks [7-10]. The organic matter is not only the hydrocarbon generation material but also the main reservoir space and seepage channel of the shale gas. Therefore, it is necessary to study the enrichment mechanism of sedimentary organic matter [11-14].

Various methods have been used to study the mechanism of organic matter enrichment in marine shales from the Yangtze area of South China. Based on the sedimentary facies of the lower member of the Lower Silurian Longmaxi Formation in the Sichuan Basin, the Upper Yangtze Region, and experimental methods (polarizing microscope, $\mathrm{X}$-ray diffraction, and elemental geochemical analysis), Mou et al. considered that the sedimentary facies have an impact on the geological conditions for shale gas accumulation [15]. Zhang et al. selected three Lower Cambrian stratigraphic sections in the Upper Yangtze region, and they tested the organic carbon content and trace elements of the rock samples [16]. In this paper, the variation characteristics of the primary biological productivity and redox conditions in different sedimentary stages of the early Cambrian were analyzed in addition to their effects on organic matter enrichment. Qiu et al. studied the organic carbon content and trace element geochemistry of 30 shale samples from the bottom of the Upper Ordovician Wufeng Formation to the Lower Silurian Longmaxi formation in the Tianba sections of the Wuxi block, Sichuan Basin, and they analyzed the enrichment characteristics and control factors of the organic matter in different intervals [17]. This work argued that sea level fluctuation controls the oxygen deficiency to an extent, which affects the deposition and enrichment of organic matter in the area. He et al. analyzed the relationship between the sedimentary environment and the enrichment of organic matter in the Upper Ordovician Wufeng black shales, the marl of the Guanyinqiao marls, and the Lower Silurian Longmaxi black shales in the Sichuan Basin, Upper Yangtze region, by using geochemical methods to determine organic carbon, sulfur, and trace elements [18].

Shale formations contain Fe, S, U, Th, Mg, Ca, Al, Fe, Mn, $\mathrm{Ba}$, and other elements, which provide important evidence for the analysis of the paleosedimentary environment [1923]. Moreover, carbon and oxygen isotopes can be used to quantitatively calculate the paleotemperature of seawater and to describe the paleoenvironment more accurately. Therefore, this paper combines core description, element analysis, and isotope calculation to study the mechanism of organic matter accumulation in marine shales.

\section{Geological Settings}

2.1. Sedimentary and Stratigraphic Characteristics. In the early Cambrian, the sedimentary facies environment of the Lower Yangtze region included ancient land, onshore, shallow shelf, deep shelf, continental slope, and ocean basin sections from northwest to southeast; meanwhile, in this period, the sedimentary environment of the Cathaysian plate included ocean basin, continental slope, deep water, shallow water, onshore, and ancient land sections from northwest to southeast (as shown in Figure 1(a)). The junction of the Yangtze plate and the Cathaysian plate was oceanic, with the deepest water found there, gradually becoming shallower on both sides [24, 25].

During the early Cambrian, due to the large-scale global transgression, a set of strata was widely deposited on the Yangtze plate and the Cathaysian plate. This set was composed of black organic-rich siliceous shale and is one of the main targets for shale gas exploration in South China. Because of its wide distribution area, it has different names in different regions. It is called the Wangyinpu Formation to the west of the Lower Yangtze region and the Hetang Formation to the east of the Lower Yangtze region [26-30].

2.2. Tectonic Characteristics. Our study area is located in the Lower Yangtze region. Based on previous studies, the original continental crust in South China was two ancient plates, the Yangtze plate and the Cathaysian plate, separated by ocean basins in the early Mesoproterozoic, and the Yangtze plate is a cratonic basin [31-38].

In the early Cambrian, the Yangtze and Cathaysian plates were under tensile stress. Due to the large-scale global transgression, a set of organic-rich shale was deposited. Subsequently, a large-scale regression occurred, and the water body became shallower, which led to the lithology change from fine-grained shales to coarse-grained clastic rocks, such as siltstone and sandstone. Influenced by the compression and collision of the Cathaysian plate in the Ordovician, the water body over the Yangtze plate continued to become shallower and changed from a clastic sedimentary system to a carbonate sedimentary system. In the late Ordovicianearly Silurian, another large-scale transgression occurred due to the melting of glaciers, which resulted in the sedimentary system being changed into a clastic rock sedimentary system again; in addition, a set of organic shale was deposited [39-41]. From the Cambrian to the Silurian, the Yangtze plate and the Cathaysian plate continually subducted and collided. By the end of the Silurian, the Yangtze plate and the Cathaysian plate merged into the unified South China plate $[42,43]$. 

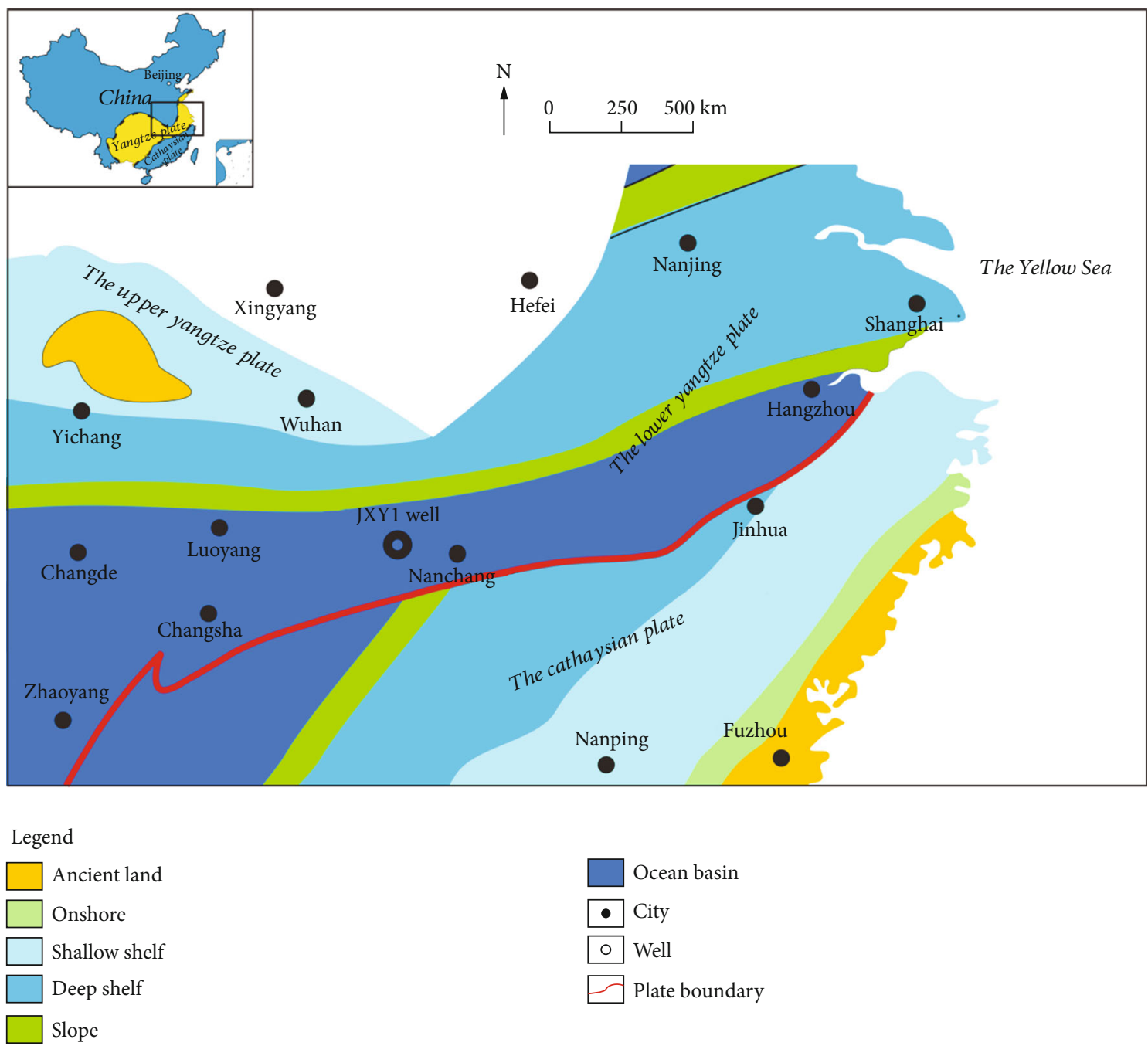

FIGURE 1: Regional sedimentary characteristics from the early Cambrian in the Lower Yangtze region of South China. (Well JXY1 is located in the Lower Yangtze region, close to the Yangtze plate and the Cathaysian plate.) Modified from references [24, 25].

\section{Samples, Experiments, and Data Sources}

In this paper, the shale samples come from the Lower Cambrian Wangyinpu Formation in Well JXY1, which is a shale gas cored well located in the Xiuwu Basin in the Lower Yangtze area of the Yangtze plate. Since the study area in the early Cambrian was marine sedimentary facies with little variation, this paper chose Well JXY1 as a typical well to study the organic matter enrichment mechanism in the Lower Yangtze area. In this study, the TOC content of 87 core samples was measured using an OG-2000V TOC analyzer. In addition, the $\mathrm{Al}, \mathrm{Fe}, \mathrm{Mn}$, and $\mathrm{Ba}$ elements of 53 core samples from the Lower Cambrian Wangyinpu Formation from Well JXY1 were analyzed by X-ray fluorescence using an Axios mAX spectrometer. Oxygen isotope analyses of core samples from $2634 \mathrm{~m}$ to $2649 \mathrm{~m}$ of the Lower Cambrian Wangyinpu Formation in Well JXY1 were determined using a Thermo Fisher MAT 253 stable isotope mass spectrometer. This paper also collected the Fe, S, U, Th, Mg, and Ca logging data of Well JXY1, as provided by Schlumberger. The sampling interval of logging data is $0.125 \mathrm{~m}$.

\section{Results and Discussion}

4.1. Redox Environment. The degree of pyritization (DOP) is the most commonly used indicator of the redox environment, which is the ratio of iron in pyrite to total reactive iron (iron in pyrite plus iron dissolved in hydrochloric acid) [44]. Because the ratio of iron in pyrite to total iron in the sample $\left(\mathrm{DOP}_{\mathrm{T}}\right)$ is approximately $\mathrm{DOP}[45,46], \mathrm{DOP}_{\mathrm{T}}$ is used instead of DOP in this study. When estimating the iron content in pyrite, all sulfur elements are assumed to exist in the form of pyrite $\left(\mathrm{FeS}_{2}\right)$. $\mathrm{DOP}_{\mathrm{T}}$ is calculated according to the following formula:

$$
\mathrm{DOP}_{\mathrm{T}}=\frac{55.85}{64.13} \times \frac{\mathrm{S}_{\mathrm{S}}}{\mathrm{Fe}_{\mathrm{S}}}
$$

55.85 and 64.13 are the atomic masses of the Fe and $\mathrm{S}$ elements in pyrite, respectively; $S_{S}$ is the measured sulfur content; and $\mathrm{Fe}_{\mathrm{S}}$ is the total $\mathrm{Fe}$ content in the sample.

Paleooxygenation facies (POF) is an important parameter to characterize the dissolved oxygen content in water, 


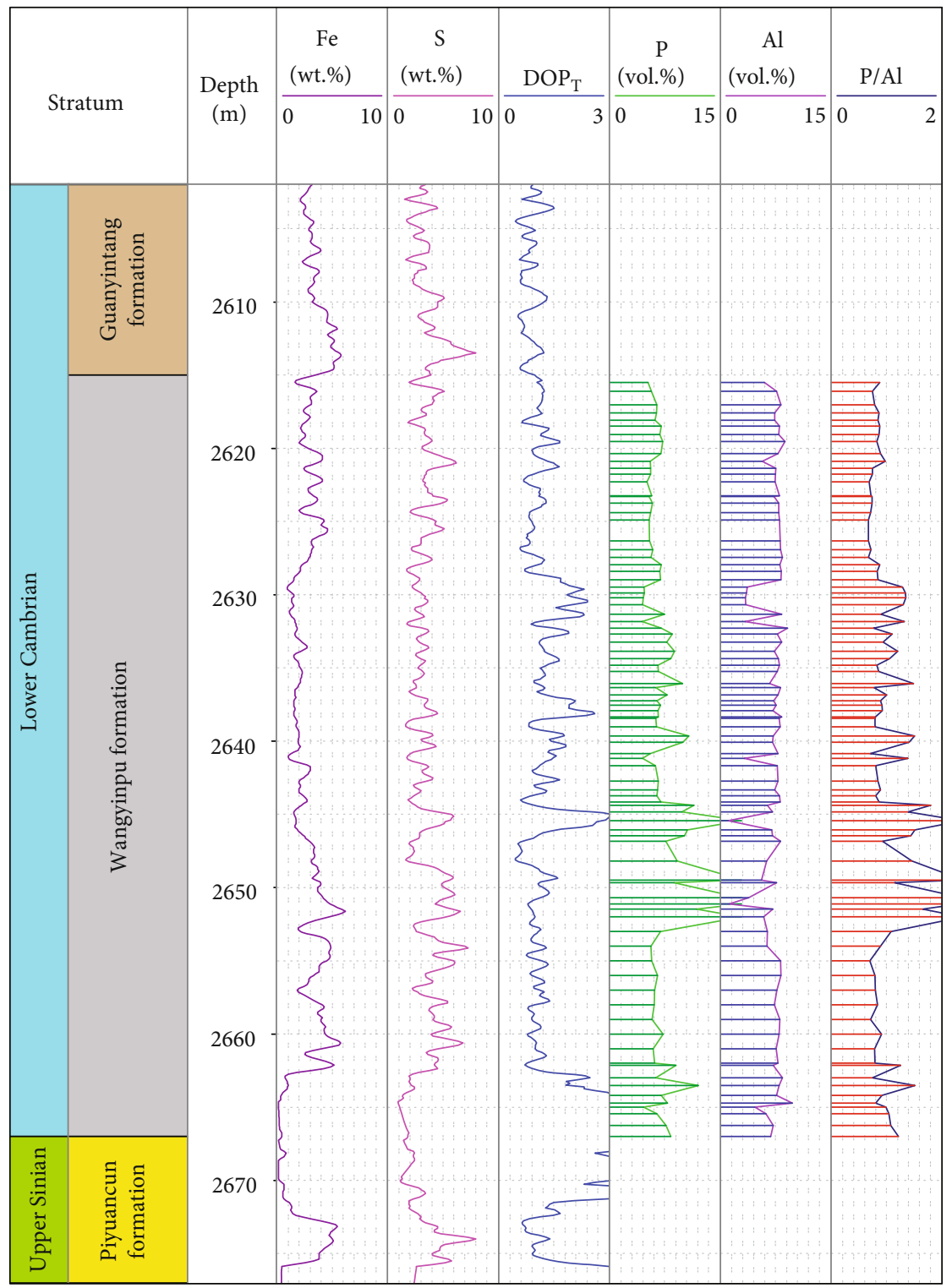

FIGURE 2: Redox environment index $\left(\mathrm{DOP}_{\mathrm{T}}\right)$ and biological productivity $(\mathrm{P} / \mathrm{Al})$ of the Lower Cambrian Wangyinpu Formation in Well JXY1. See Figure 1 for the well location.

including the oxic facies $\left(\mathrm{O}_{2}\right.$ content $\left.>2 \mathrm{~mL} / \mathrm{L}\right)$, dysoxic facies $\left(\mathrm{O}_{2}\right.$ content between 0.2 and $\left.2 \mathrm{~mL} / \mathrm{L}\right)$, suboxic facies $\left(\mathrm{O}_{2}\right.$ content between 0 and $\left.0.2 \mathrm{~mL} / \mathrm{L}\right)$, and anoxic facies $\left(\mathrm{O}_{2}\right.$ content $\left.=0 \mathrm{~mL} / \mathrm{L}\right)$ [47]. Pang et al. and Zhang et al. defined DOP characteristics in three sedimentary environments: (1) aerobic environment (including oxic and dysoxic facies), $\mathrm{DOP}_{\mathrm{T}}<0.42$; (2) anaerobic environment without $\mathrm{H}_{2} \mathrm{~S}$ (suboxic facies), $0.42<\mathrm{DOP}_{\mathrm{T}}<0.75$; and (3) anaerobic environment without oxygen but with $\mathrm{H}_{2} \mathrm{~S}$ (anoxic facies), $\mathrm{DOP}_{\mathrm{T}}>0.75[40,41]$. In this paper, $\mathrm{DOP}_{\mathrm{T}}$ is calculated by using the logging data of $\mathrm{Fe}$ and $\mathrm{S}$ elements of the Lower Cambrian Wangyinpu Formation of the Cambrian section in Well JXY1. As shown in Figure 2, the $\mathrm{DOP}_{\mathrm{T}}$ of the whole well of the Wangyinpu Formation was higher than 0.75 and was higher than 1 in the middle part of the Wangyinpu Formation; thus, during the early Cambrian Wangyinpu sedimentary period, the seawater in the research area was an anaerobic environment with $\mathrm{H}_{2} \mathrm{~S}$, and its reducibility was the strongest in the middle stage of the Wangyinpu sedimentary period.

4.2. Biological Productivity. The premise of organic matter enrichment in shales is that the environment provides sufficient organic matter sources; thus, the seawater needs to have a high level of primary productivity [48]. Here, $\mathrm{P}$ is not only one of the most critical nutrient elements in biological metabolism but also a component of many marine biological skeletons, which are deposited in sediments after the death of organisms. Therefore, $\mathrm{P}$ is widely used to determine the level of biological productivity $[49,50]$. Since $\mathrm{P}$ in terrestrial and authigenic minerals may cause inaccuracies in determining biological productivity, $\mathrm{P} / \mathrm{Al}$ can better reflect the primary productivity of paleooceans than $\mathrm{P}[51,52]$. As shown in Figure 2, the $\mathrm{P} / \mathrm{Al}$ in the middle part of the Lower 


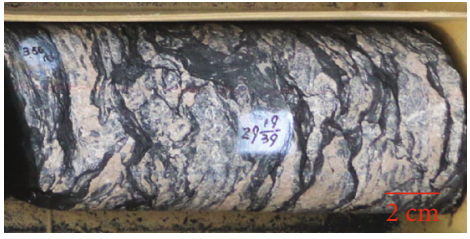

(a)

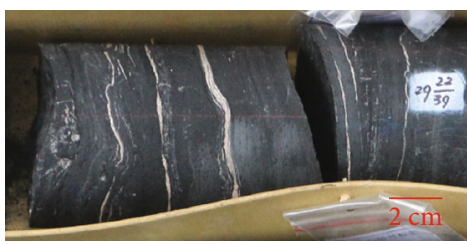

(c)

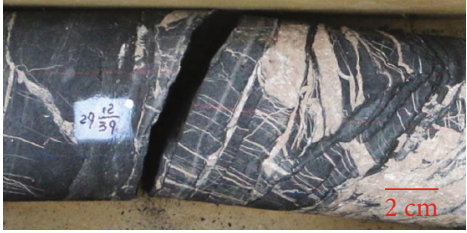

(b)

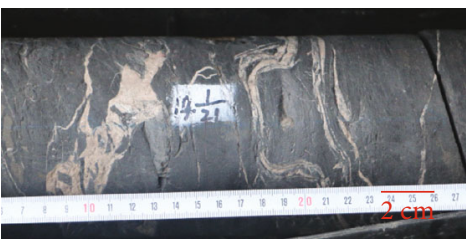

(d)

Figure 3: Sedimentary structures of the Wangyinpu shales in Well JXY1: (a) vein structure, (b) contraction-like structures, and (c, d) contemporaneous deformed structures. See Figure 1 for the well location.

Cambrian Wangyinpu Formation is higher than those of other sections in the JXY1 well, which indicates that the level of biological productivity is highest in the middle stage of the early Cambrian Wangyinpu sedimentary period.

\subsection{Hydrothermal Activities}

4.3.1. Core Description. Shales with horizontal bedding and block bedding were developed in the deep sea where the sedimentary environment was relatively calm [53-56]. If there were hydrothermal activities on the seabed, some special sedimentary structures are easily formed in the relatively soft seabed sediments due to the high velocity and large flow rate, so these structures would provide evidence of hydrothermal activities.

(1) Vein Structures. A large number of vein-like ore bodies are often found in the Lower Cambrian Wangyinpu shales, which are distributed in the form of network veins. It shows that this is a structure formed by fractures filled with barite (Figure 3(a)). Because the seabed sediments were affected by hydrothermal fluids before consolidation, strong deformation structures were found in the shales.

(2) Contraction-Like Structures. Some structures similar to desiccation cracks were often found in carbonaceous shales, and the cracks were often filled with barite components (Figure 3(b)), which are typical features of cracks formed by hydrothermal exhalation.

(3) Contemporaneous Deformed Structures. Clay minerals, organic matter, and siliceous minerals were deposited in the deep sea, forming soft sediments. Due to the influence of hydrothermal exhalation, a large number of contemporaneous deformed structures, such as convoluted structures, were formed on these sediments (Figures 3(c) and 3(d)) [57, 58].

4.3.2. Elemental Analysis. To accurately determine whether there is hydrothermal activity in the study area, excess siliceous mineral content was used for analysis in this study

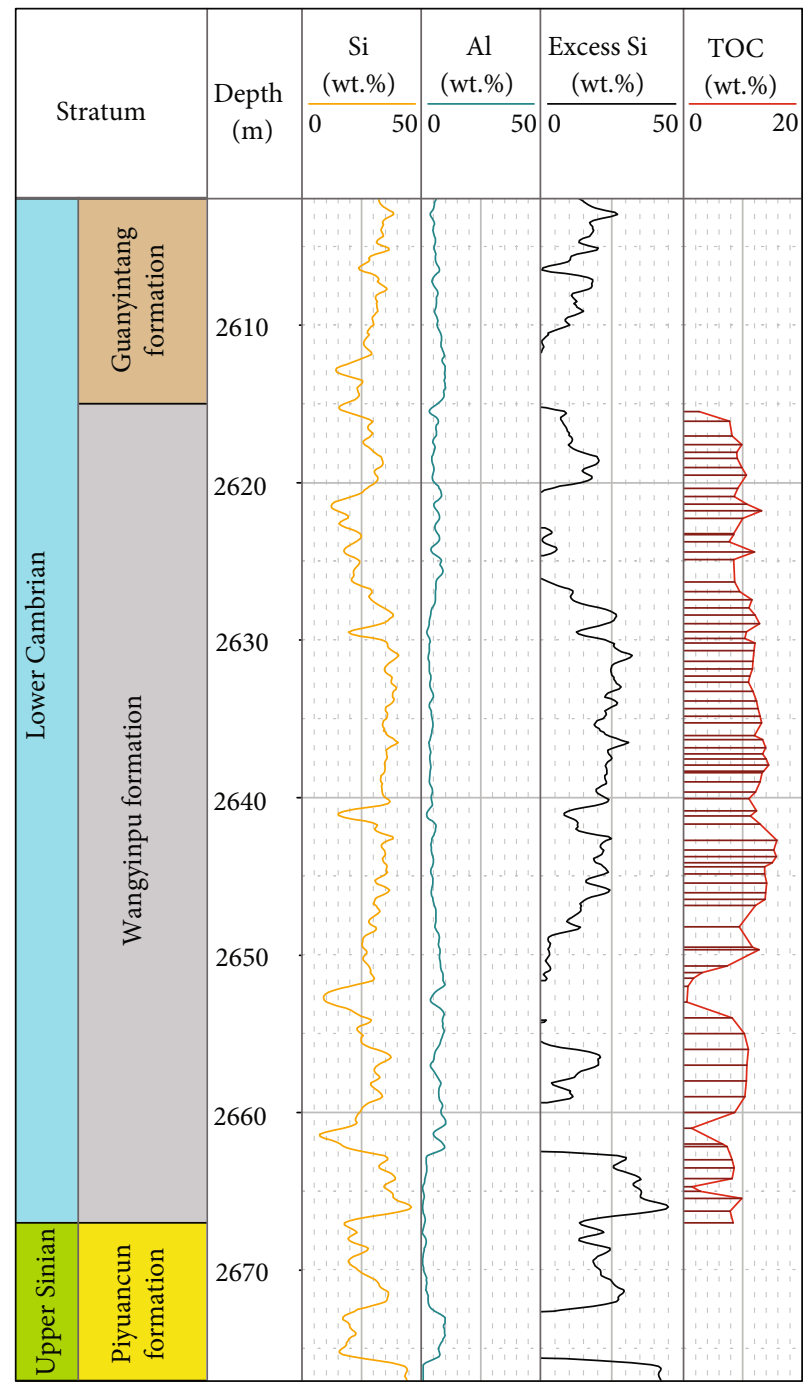

FIgURE 4: Excess silicon and TOC content of the Lower Cambrian Wangyinpu Formation in the Yangtze area from Well JXY1. See Figure 1 for the well location. 


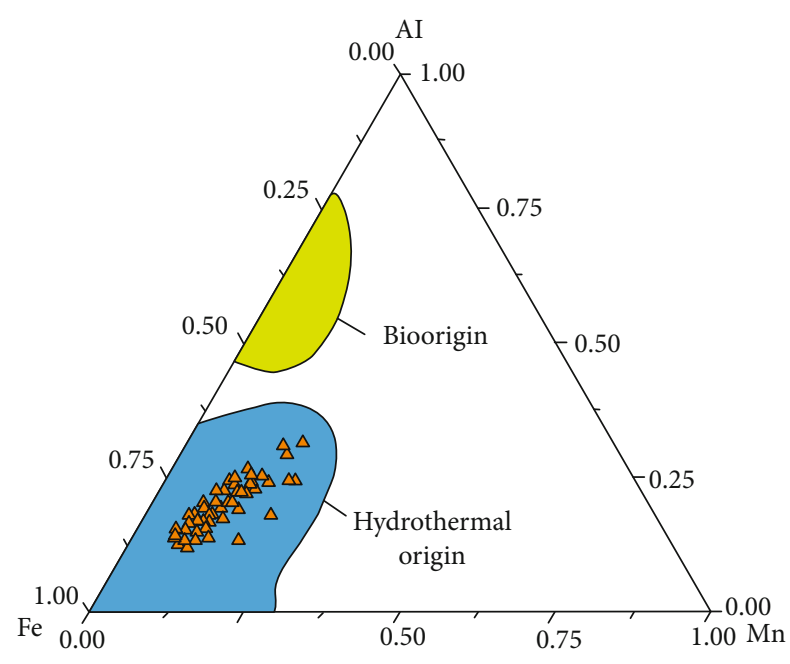

Figure 5: Through the Al-Fe-Mn ternary plot analysis, siliceous minerals from the Lower Cambrian Wangyinpu Formation in Well JXY1 contain excess siliceous minerals, which are derived from hydrothermal origins. See Figure 1 for the well location.

[59-63]. Excess siliceous mineral content (abbreviated $\mathrm{Si}_{\mathrm{ex}}$ ) refers to all siliceous minerals except those from terrestrial clastic deposition and can be calculated by the following formula:

$$
\mathrm{Si}_{\mathrm{ex}}=\mathrm{Si}_{\mathrm{s}}-\left[\left(\frac{\mathrm{Si}}{\mathrm{Al}}\right)_{\mathrm{bg}} \times \mathrm{Al}_{\mathrm{s}}\right] .
$$

$\mathrm{Si}_{\mathrm{s}}$ is the $\mathrm{Si}$ content in the samples, $\mathrm{Al}_{\mathrm{S}}$ is the $\mathrm{Al}$ content in the samples, and the $(\mathrm{Si} / \mathrm{Al})_{\mathrm{bg}}$ value is 3.11 , which is the average content in shales [64].

Figure 4 shows the results when using this formula to calculate the excess siliceous mineral content from the Lower Cambrian Wangyinpu Formation section of Well JXY1. Excess siliceous minerals existed in most intervals of the Wangyinpu Formation. In the layers where excess siliceous minerals are present, the excess siliceous mineral content in half of the layers is between $20 \%$ and $30 \%$, and the excess siliceous content in some layers is between $30 \%$ and $40 \%$, even reaching as high as $40 \%$ to $50 \%$. Wedepohl, Adachi et al., and Yamamoto proposed a method of using the AlFe-Mn ternary plot to determine whether siliceous minerals are derived from hydrothermal origins or biogenesis [6567]. In this paper, the elemental analysis values of $\mathrm{Al}, \mathrm{Fe}$, and $\mathrm{Mn}$ in the layers with excess siliceous minerals from the Lower Cambrian Wangyinpu Formation from Well JXY1 are plotted in the triangular diagram. As shown in Figure 5, the numerical value falls within the range of a hydrothermal origin, which indicates that the excess siliceous minerals are derived from a hydrothermal origin.

4.3.3. Hydrothermal Temperature Calculation. Oxygen isotopes in shale can be used to determine the genesis of siliceous minerals $[68,69]$. Siliceous minerals from different biogenesis origins have different $\delta^{18} \mathrm{O}$ values. The specific method is shown in Table 1.

The $\delta^{18} \mathrm{O}$ value of the Lower Cambrian Wangyinpu Formation from Well JXY1 is in accordance with the PDB standard. The experimental results are shown in Table 2 . According to the formula

$$
\delta_{\mathrm{SMOW}}=1.03086 \delta_{\mathrm{PDB}}+30.86 \text {. }
$$

The $\delta^{18} \mathrm{O}$ value under the PDB standard is converted into the $\delta^{18} \mathrm{O}$ value of the SMOW standard.

Table 2 shows that the $\delta^{18} \mathrm{O}$ values of the SMOW standard in the Lower Cambrian Wangyinpu shales are 16.85\% and $20.07 \%$, indicating that the oxygen isotope values of the shale siliceous minerals in the study area are within the range of hydrothermal origins (12.2\% to $23.6 \%$ ), which means that the Lower Cambrian Wangyinpu shales were affected by hydrothermal activities.

Oxygen isotopes in the shale can be used to calculate the temperature of the ancient ocean, as shown in the following two empirical formulas:

$$
\begin{aligned}
& \delta^{18} \mathrm{O}(\text { shale })-\delta^{18} \mathrm{O}(\text { seawater })=3.09 \times \frac{10^{6}}{T^{2}}-3.29, \\
= & 5.0-4.1 \times\left[\delta^{18} \mathrm{O}(\text { shale })-\delta^{18} \mathrm{O}(\text { seawater })-40\right] .
\end{aligned}
$$

$\delta^{18} \mathrm{O}$ (shale) is the oxygen isotope in shale, and $\delta^{18} \mathrm{O}$ (seawater) is the oxygen isotope in a sedimentary medium (seawater). In formula (4), $T$ is the thermodynamic temperature.

In the aforementioned formulas, the $\delta^{18} \mathrm{O}$ in paleoseawater is unknown, but previous studies show that the $\delta^{18} \mathrm{O}$ in seawater has changed very little, considering the past and present values. Thus, in this study, the $\delta^{18} \mathrm{O}$ of paleoseawater is assumed to be the same as that of present seawater values, which is $0 \%$.

This formula has been used to calculate the seawater temperature of other areas during the deposition of Lower Silurian, Lower Cambrian, and siliceous rocks. This paper also uses two formulas to calculate the seawater temperature with reference to the previous papers [70-72]. Based on the above assumptions, the results of the paleoseawater temperature calculations are shown in Table 2. According to formula (4), the temperature calculation results of the early Cambrian paleoseawater in the study area (Nos. 1-2) were $90.54^{\circ} \mathrm{C}$ and $118.56^{\circ} \mathrm{C}$, while according to formula (5), the results were $86.71^{\circ} \mathrm{C}$ and $99.92^{\circ} \mathrm{C}$, respectively. According to Hearing et al. (2018), the seawater temperature near the equator in the early Cambrian ranged from $35^{\circ} \mathrm{C}$ to $45^{\circ} \mathrm{C}$, indicating that the paleoseawater between the Yangtze plate and the Cathaysian plate in the early Cambrian was greatly affected by hydrothermal activities.

4.3.4. Effects of Hydrothermal Activities on Sedimentary Organic Matter Enrichment. The existence of hydrothermal silicon in Well JXY1 was related to the active compression between the Yangtze and Cathaysian plates during the early Cambrian [31-33]. The hydrothermal activities formed siliceous minerals in shale, which had an impact on the redox 
TABLE 1: Sources of siliceous minerals determined by $\delta^{18} \mathrm{O}$ value.

\begin{tabular}{|c|c|c|c|c|}
\hline$\delta^{18} \mathrm{O}(\mathrm{SMOW})$ & & & & \\
\hline Siliceous sources & Magmatic rocks & Metamorphic rocks & Hydrothermal & Arenaceous quartz \\
\hline Range & $8.3 \%$ $11.2 \%$ & $11.2 \%$ 16.4\%o & $12.2 \%$ 23.6\%o & $10.3 \%$ о $12.5 \%$ о \\
\hline
\end{tabular}

TABle 2: Conversion of $\delta^{18} \mathrm{O}$ values under the PDB standard and SMOW standard and calculation results of paleoseawater temperature.

\begin{tabular}{ccccc}
\hline \multirow{2}{*}{ No. } & \multicolumn{2}{c}{$\delta^{18} \mathrm{O}(\%)$} & \multicolumn{2}{c}{ Paleotemperature of seawater $\left({ }^{\circ} \mathrm{C}\right)$} \\
& PDB & SMOW & By Equation $(4)$ & By Equation $(5)$ \\
\hline 1 & -10.47 & 20.07 & 90.54 & 86.71 \\
2 & -13.59 & 16.85 & 118.56 & 99.92 \\
\hline
\end{tabular}

conditions and bioproductivity of water bodies, and thus, this affected the abundance of sedimentary organic matter.

The research conducted by Sun et al. and Zhang et al. found that reduced hydrothermal fluids sank to the seafloor to form an oxygen-deficient environment that was conducive to organic matter preservation [73-75]. The redox conditions of the water body were also related to the hydrothermal activity in the study area during the early Cambrian. Figures 2 and 4 show that in some layers with higher hydrothermal silicon content, the $\mathrm{DOP}_{\mathrm{T}}$ was also high, which shows a positive correlation with the hydrothermal silicon content; in addition, this indicated frequent hydrothermal activities in the early Cambrian. The $\mathrm{DOP}_{\mathrm{T}}$ of all layers in the Lower Cambrian Wangyinpu Formation was greater than 0.75 , with some layers being greater than 1.5, which indicates that during the early Cambrian Wangyinpu sedimentary period, the water body in the research area was an anaerobic environment with $\mathrm{H}_{2} \mathrm{~S}$.

It is generally accepted by many scholars that hydrothermal activities are closely related to paleoproductivity. Halbach et al. studied the hydrothermal activity in the Fiji Basin, and they found that the closer the area is to the hydrothermal activity zone, the greater the number and activity of organisms [76]. In addition, in the hydrothermal activity zone, the abundance of these organisms will be 1 to 3 orders of magnitude higher than that in the normal ocean surface. McKibben et al. (1990) and Korzhinsky et al. (1994) argued that hydrothermal fluids could carry many rare elements on the surface of the crust and that these dissolved trace elements contain several essential nutrients $(\mathrm{Si}, \mathrm{N}, \mathrm{P}, \mathrm{Fe}$, and $\mathrm{Zn}$ ) for marine life. In addition, trace elements existing in the bodies of these organisms can be in the form of "sea snow," which sinks to the seafloor after biological death and provides a source of organic enrichment for the source rocks $[77,78]$.

Similarly, biological productivity in the study area also has some correlation with hydrothermal activities during the early Cambrian. As shown in Figures 2 and 4, hydrothermal activity in the early Cambrian was frequent. Among the layers with high silicon content, the $\mathrm{P} / \mathrm{Al}$ values used to char- acterize biological productivity were relatively higher than those of the other layers with weak hydrothermal activities.

The relationships between the $\mathrm{DOP}_{\mathrm{T}}$ and TOC content and the $\mathrm{P} / \mathrm{Al}$ and TOC content were statistically analyzed (Figure 6). It was found that both of them were positively correlated, which means that the higher the reducibility of water and the higher the biological productivity, the higher the TOC content of shale. Active hydrothermal activities during the early Cambrian resulted in a high level of biological productivity and an anaerobic environment with $\mathrm{H}_{2} \mathrm{~S}$, and this caused an increase in the TOC content of up to $6.5 \%-14 \%$ in the lower part of the present-day Wangyinpu Formations (Figure 5).

4.4. Organic Matter Enrichment Mechanism. In the early Cambrian, the Yangtze plate and the Cathaysian plate were separated by the paleoocean. During the Wangyinpu sedimentary period, large-scale transgression occurred [79]. Hydrothermal fluids rich in silicon, uranium, and other mineral elements entered the ocean basin in the deep crust due to the extension between the Cathaysian plate and the Yangtze plate and to the shelf area under the action of upwelling. Its temperature ranged from 90 to $120^{\circ} \mathrm{C}$. On the one hand, the hydrothermal solution enters the surface of the sea and carries nutrients to promote the growth and reproduction of plankton and to increase biological productivity. On the other hand, it forms an anaerobic environment without oxygen but with $\mathrm{H}_{2} \mathrm{~S}$ on the bottom of the sea, which is beneficial to the preservation of the original sedimentary organic matter. Both factors are beneficial to the enrichment of sedimentary organic matter (Figure 7).

\section{Conclusions}

In this paper, the Lower Cambrian marine shales from Well JXY1 in the Yangtze area of South China are selected for study as typical shales. Through TOC content testing, elemental analysis of cuttings, and the collected elemental well logging data, the following conclusions can be drawn regarding the organic matter enrichment mechanism:

(1) During the early Cambrian Wangyinpu sedimentary period, the bottom layer of seawater was in an anaerobic environment with the appearance of $\mathrm{H}_{2} \mathrm{~S}$, and the oxygen concentration was approximately $0 \mathrm{~mL} / \mathrm{L}$. The reducibility in the bottom layer of seawater was strongest in the middle stage of this period

(2) The biological productivity was highest in the middle stage of the Wangyinpu sedimentary period but relatively low in other stages 


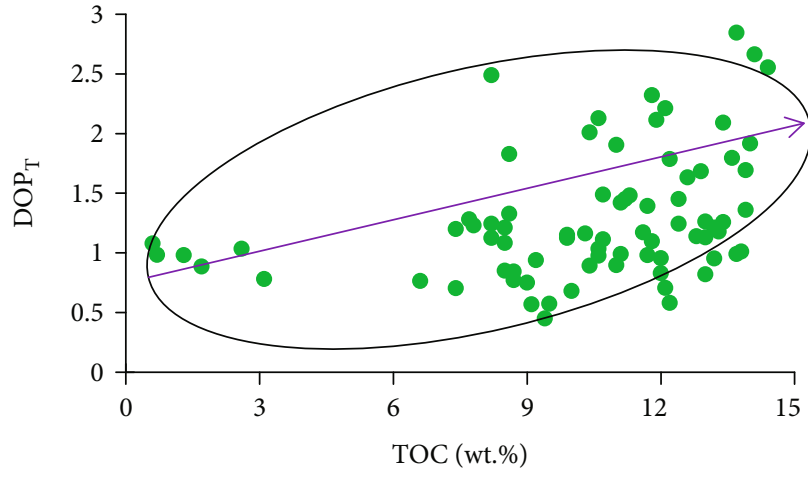

(a)

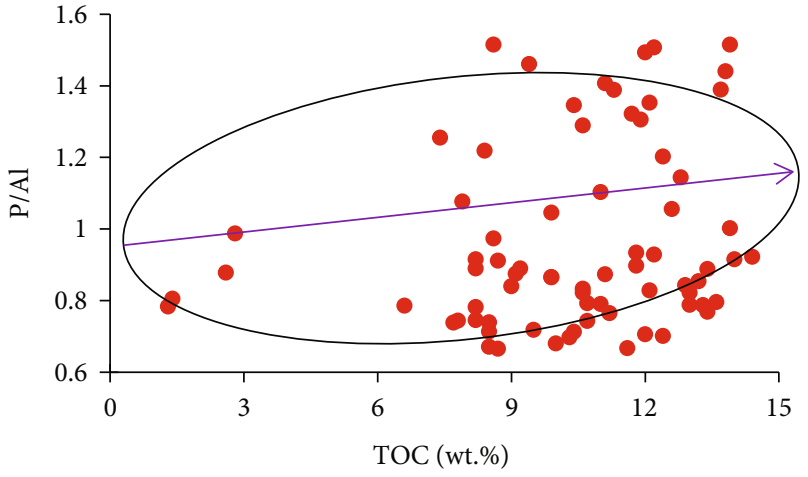

(b)

FIgure 6: The correlation diagrams of $\mathrm{DOP}_{\mathrm{T}}$ and TOC content (a) and $\mathrm{P} / \mathrm{Al}$ and TOC content (b) in the redox environment are all positive.

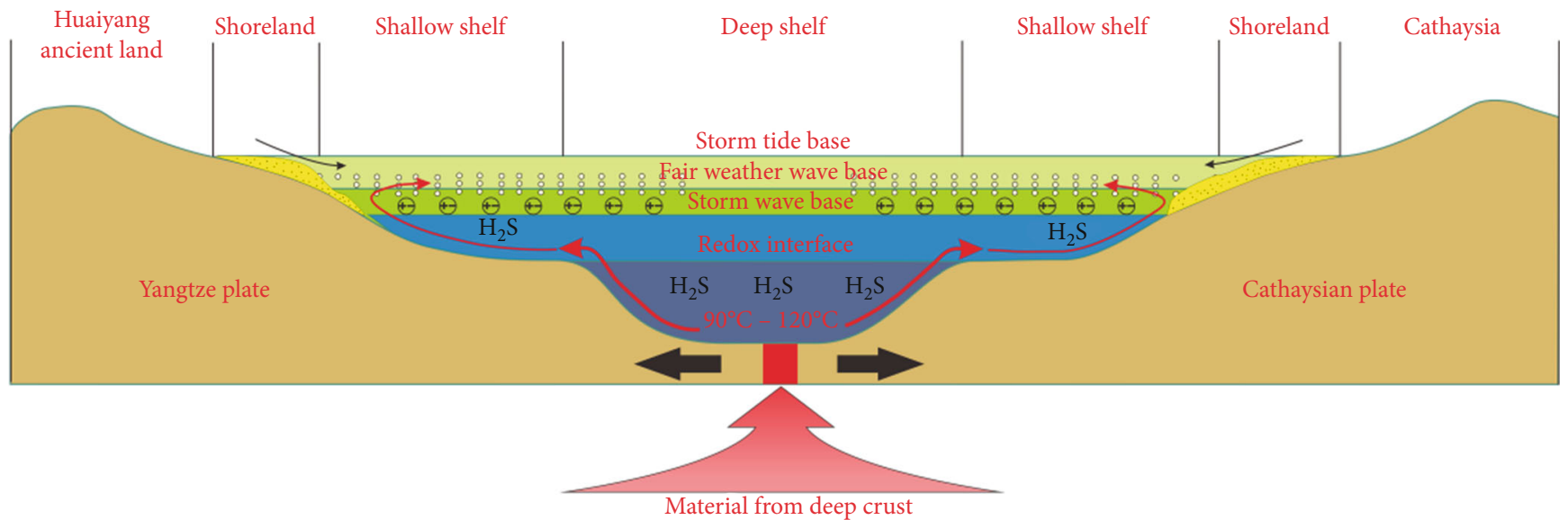

Legend
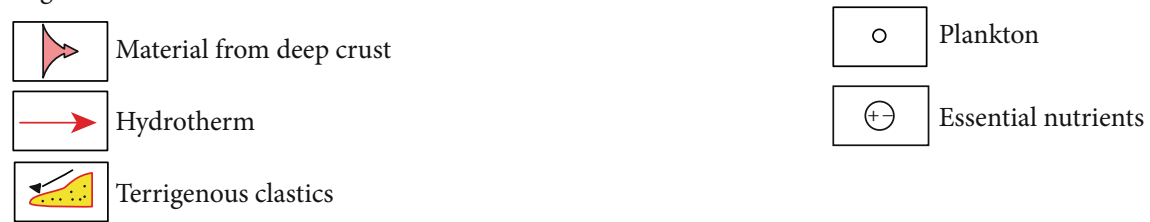

FIgURE 7: Mechanism of organic matter enrichment in the early Cambrian Wangyinpu Formation in the Lower Yangtze area.

(3) The paleoseawater between the Yangtze plate and the Cathaysian plate in the early Cambrian was greatly affected by hydrothermal activities, and its temperature ranged from $90^{\circ} \mathrm{C}$ to $120^{\circ} \mathrm{C}$. Active hydrothermal activities during the early Cambrian resulted in a high level of biological productivity and an anaerobic environment with $\mathrm{H}_{2} \mathrm{~S}$, and this caused an increase in the TOC content of up to $6.5 \%-14 \%$ in the lower part of the present-day Wangyinpu Formations

\section{Data Availability}

Some of the data are contained in a published source cited in the references. All the data in this article are accessible to the readers.

\section{Additional Points}

Highlights. (1) The degree of pyritization (DOP) of the lower layer of the early Cambrian seawater in the Lower Yangtze region indicates that it is an anaerobic environment with $\mathrm{H}_{2} \mathrm{~S}$, and its reducibility was strongest in the early and middle sedimentary period. (2) The analysis of elements $(\mathrm{P} / \mathrm{Al})$ shows that the biological productivity was the highest in the middle sedimentary periods. (3) In the early Cambrian, the seawater between the Yangtze plate and the Cathaysian plate was greatly affected by hydrothermal activities, which resulted in high biological productivity and water bodies in an anaerobic environment with $\mathrm{H}_{2} \mathrm{~S}$. 


\section{Conflicts of Interest}

There are no conflicts of interest with respect to the results of this paper.

\section{Acknowledgments}

This study was supported by the China Postdoctoral Science Foundation (No. 2019M663560), the National Natural Science Foundation of China (No. 41872166), and open funds from the State Key Laboratory of Shale Oil and Gas Enrichment Mechanisms and Effective Development.

\section{References}

[1] J. B. Curtis, "Fractured shale-gas systems," AAPG Bulletin, vol. 86, no. 11, pp. 1921-1938, 2002.

[2] S. L. Montgomery, D. M. Jarvie, K. A. Bowker, and R. M. Pollastro, "Mississippian Barnett shale, Fort Worth basin, north-central Texas: gas-shale play with multi-trillion cubic foot potential," AAPG Bulletin, vol. 89, no. 2, pp. 155-175, 2005.

[3] K. Zhang, Z. Jiang, X. Xie et al., "Lateral percolation and its effect on shale gas accumulation on the basis of complex tectonic background," Geofluids, vol. 2018, Article ID 5195469, 11 pages, 2018.

[4] K. Zhang, Y. Song, C. Jia et al., "Vertical sealing mechanism of shale and its roof and floor and effect on shale gas accumulation, a case study of marine shale in Sichuan basin, the Upper Yangtze area," Journal of Petroleum Science and Engineering, vol. 175, no. 2019, pp. 743-754, 2019.

[5] K. Zhang, Y. Song, S. Jiang et al., "Shale gas accumulation mechanism in a syncline setting based on multiple geological factors: an example of southern Sichuan and the Xiuwu Basin in the Yangtze region," Fuel, vol. 241, no. 2019, pp. 468-476, 2019.

[6] K. Zhang, C. Jia, Y. Song et al., "Analysis of Lower Cambrian shale gas composition, source and accumulation pattern in different tectonic backgrounds: a case study of Weiyuan Block in the Upper Yangtze region and Xiuwu Basin in the Lower Yangtze region," Fuel, vol. 263, no. 2020, p. 115978, 2020.

[7] L. Chen, Y. Lu, S. Jiang, J. Li, T. Guo, and C. Luo, "Heterogeneity of the Lower Silurian Longmaxi marine shale in the southeast Sichuan Basin of China," Marine and Petroleum Geology, vol. 65, pp. 232-246, 2015.

[8] L. Chen, Y. Lu, S. Jiang et al., "Sequence stratigraphy and its application in marine shale gas exploration: a case study of the Lower Silurian Longmaxi Formation in the Jiaoshiba shale gas field and its adjacent area in southeast Sichuan Basin, SW China," Journal of Natural Gas Science and Engineering, vol. 27, pp. 410-423, 2015.

[9] X. Chen, L. Chen, X. Guo, and C. Wang, "Geochemical characteristics of shale gas in the Silurian Longmaxi Formation, Jiaoshiba area, southeast Sichuan Basin, China," Energy \& Fuels, vol. 33, pp. 8045-8054, 2019.

[10] S. Jiang, L. Chen, Y. Wu, Z. Jiang, and E. McKenna, "Hybrid plays of Upper Triassic Chang7 lacustrine source rock interval of Yanchang Formation, Ordos Basin, China," Journal of Petroleum Science and Engineering, vol. 159, pp. 182-196, 2017.

[11] B. Li, Q. Xia, J. Peng, S. Yang, Q. Xu, and L. Zeng, "Characteristics and dolomitization of the Lower Qiulitage group reser- voir in Bachu Uplift, Tarim Basin, China," Earth Sciences Research Journal, vol. 23, no. 3, pp. 199-208, 2019.

[12] J. Peng, J. Liu, Y. Wang, and J. Liu, "Origin and controlling factors of chlorite coatings-an example from the reservoir of T3x Group of the Baojie area, Sichuan Basin, China," Petroleum Science, vol. 6, no. 4, pp. 376-382, 2009.

[13] J. Peng, H. Zhang, and X. Lin, "Study on characteristics and genesis of botryoidal dolostone of the Upper Sinian Dengying Formation: a case study from Hanyuan region, Sichuan, China," Carbonates and Evaporites, vol. 33, no. 2, pp. 285299, 2018.

[14] K. Zhang, Z. Li, S. Jiang et al., "Comparative analysis of the siliceous source and organic matter enrichment mechanism of the Upper Ordovician-Lower Silurian shale in the UpperLower Yangtze area," Minerals, vol. 8, no. 7, p. 283, 2018.

[15] C. Mou, X. Wang, Q. Wang et al., "Relationship between sedimentary facies and shale gas geological conditions of the Lower Silurian Longmaxi Formation in southern Sichuan Basin and its adjacent areas," Journal of Palaeogeography, vol. 18, no. 3, pp. 457-472, 2016.

[16] K. Zhang, Z. Jiang, L. Yin et al., "Controlling functions of hydrothermal activity to shale gas content-taking lower Cambrian in Xiuwu Basin as an example," Marine and Petroleum Geology, vol. 85, no. 2017, pp. 177-193, 2017.

[17] Z. Qiu, Z. Jiang, D. Dong et al., "Organic matter enrichment model of the shale in Wufeng-Longmaxi formation of Wuxi area," Journal of China University of Mining \& Technology, vol. 46, no. 5, pp. 1134-1143, 2017.

[18] L. He, Y. Wang, D. Chen, Q. Wang, and C. Wang, "Relationship between sedimentary environment and organic matter accumulation in the black shale of Wufeng-Longmaxi Formations in Nanchuan area, Chongqing," Natural Gas Geoscience, vol. 30, no. 2, pp. 203-218, 2018.

[19] X. Zhao, K. Qi, L. Liu, C. Gong, and W. D. Mccaffrey, "Development of a partially-avulsed submarine channel on the Niger Delta continental slope: architecture and controlling factors," Marine and Petroleum Geology, vol. 95, no. 2018, pp. 30-49, 2018.

[20] X. Zhao, M. Li, K. Qi et al., "Development of a distinct submarine depositional system on a topographically complex Niger Delta slope," Geological Journal, vol. 55, no. 5, pp. 3732-3747, 2020.

[21] X. Zhao, K. Qi, M. Patacci, C. Tan, and T. Xie, "Submarine channel network evolution above an extensive masstransport complex: a 3D seismic case study from the Niger delta continental slope," Marine and Petroleum Geology, vol. 104, no. 2019, pp. 231-248, 2019.

[22] J. Shen, Q. Feng, T. J. Algeo et al., "Sedimentary host phases of mercury $(\mathrm{Hg})$ and implications for use of $\mathrm{Hg}$ as a volcanic proxy," Earth and Planetary Science Letters, vol. 543, article 116333, 2020.

[23] S. Zheng, Q. Feng, N. Tribovillard, T. Servais, Y. Zhang, and B. Gao, "New insight into factors controlling organic matter distribution in Lower Cambrian source rocks: a study from the Qiongzhusi Formation in South China," Journal of Earth Science, vol. 31, no. 1, pp. 181-194, 2020.

[24] M. Zhu, J. Zhang, A. Yang, G. Li, M. Steiner, and B. D. Erdtmann, "Sinian-Cambrian stratigraphic framework for shallow-to deepwater environments of the Yangtze Platform: an integrated approach," Progress in Natural Science, vol. 13, no. 12, pp. 951-960, 2003. 
[25] M.-Y. Zhu, L. E. Babcock, and S.-C. Peng, "Advances in Cambrian stratigraphy and paleontology: integrating correlation techniques, paleobiology, taphonomy and paleoenvironmental reconstruction," Palaeoworld, vol. 15, no. 3-4, pp. 217-222, 2006.

[26] D. Lv, Z. Li, H. Liu et al., "The characteristics of coal and oil shale in the coastal sea areas of Huangxian coalfield, eastern China," Oil Shale, vol. 32, no. 3, pp. 204-217, 2015.

[27] X. Qiu, C. Liu, G. Mao, Y. Deng, F. Wang, and J. Wang, "Major, trace and platinum-group element geochemistry of the Upper Triassic nonmarine hot shales in the Ordos basin, Central China," Applied Geochemistry, vol. 53, pp. 42-52, 2015.

[28] J. Wu, C. Liang, Z. Jiang, and C. Zhang, "Shale reservoir characterization and control factors on gas accumulation of the Lower Cambrian Niutitang shale, Sichuan Basin, South China," Geological Journal, vol. 54, no. 3, pp. 1604-1616, 2018.

[29] C. Han, M. Han, Z. Jiang et al., "Source analysis of quartz from the Upper Ordovician and Lower Silurian black shale and its effects on shale gas reservoir in the Southern Sichuan Basin and its periphery, China," Geological Journal, vol. 54, no. 1, pp. 438-449, 2019.

[30] J. Wu, C. Liang, Z. Hu et al., "Sedimentation mechanisms and enrichment of organic matter in the Ordovician Wufeng Formation-Silurian Longmaxi Formation in the Sichuan Basin," Marine and Petroleum Geology, vol. 101, pp. 556$565,2019$.

[31] Z. Li, L. Zhang, and C. M. Powell, "South China in Rodinia: part of the missing link between Australia-East Antarctica and Laurentia?," Geology, vol. 23, no. 5, pp. 407-410, 1995.

[32] Z.-X. Li, X.-h. Li, H. Zhou, and P. D. Kinny, "Grenvillian continental collision in South China: new SHRIMP U-Pb zircon results and implications for the configuration of Rodinia," Geology, vol. 30, no. 2, pp. 163-166, 2002.

[33] J. Wang and Z. Li, "History of Neoproterozoic rift basins in South China: implications for Rodinia break-up," Precambrian Research, vol. 122, no. 1-4, pp. 141-158, 2003.

[34] C. Han, B. Li, C. Zai, M. Wu, and W. Lin, "The lithofacies and reservoir characteristics of the Upper Ordovician and Lower Silurian black shale in the Southern Sichuan Basin and its periphery, China," Marine and Petroleum Geology, vol. 75, pp. 181-191, 2016.

[35] D. Lv, B. Li, D. Rui, D. Wang, and H. Liu, "Oil shale paleoproductivity disturbed by sea water in a coal and oil shale bearing succession: a case study from the Paleogene Huangxian basin of eastern China," Journal of Natural Gas Science and Engineering, vol. 139, pp. 62-70, 2016.

[36] D. Lv, D. Wang, Z. Li, H. Liu, and Y. Li, "Depositional environment, sequence stratigraphy and sedimentary mineralization mechanism in the coal bed- and oil shale-bearing succession: a case from the Paleogene Huangxian Basin of China," Journal of Natural Gas Science and Engineering, vol. 148, pp. 32-51, 2017.

[37] C. Liang, Z. Jiang, Y. Cao, J. Zhang, and L. Guo, "Sedimentary characteristics and paleoenvironment of shale in the WufengLongmaxi Formation, North Guizhou Province, and its shale gas potential," Journal of Earth Science, vol. 28, no. 6, pp. 1020-1031, 2017.

[38] J. Liu, Y. Yao, D. Elsworth, D. Liu, Y. Cai, and L. Dong, "Vertical heterogeneity of the shale reservoir in the Lower Silurian Longmaxi Formation: analogy between the southeastern and Northeastern Sichuan Basin, SW China," Minerals, vol. 7, no. 8, p. 151, 2017.

[39] J. Li, S. Zhou, G. Gaus et al., "Characterization of methane adsorption on shale and isolated kerogen from the Sichuan Basin under pressure up to $60 \mathrm{MPa}$ : experimental results and geological implications," International Journal of Coal Geology, vol. 189, pp. 83-93, 2018.

[40] H. Pang, X.-q. Pang, L. Dong, and X. Zhao, "Factors impacting on oil retention in lacustrine shale: Permian Lucaogou Formation in Jimusaer Depression, Junggar Basin," Journal of Natural Gas Science and Engineering, vol. 163, pp. 79-90, 2018.

[41] M. Zhang, Z. Li, and J. Yin, "Sedimentary and geochemical characteristics of oil shale in the Permian Lucaogou formation in the southeastern Junggar basin, Northwest China: implications for sedimentary environments," Oil Shale, vol. 35, no. 2, pp. 97-112, 2018.

[42] K. Zhang, Y. Song, S. Jiang et al., “Accumulation mechanism of marine shale gas reservoir in anticlines: a case study of the southern Sichuan Basin and Xiuwu Basin in the Yangtze region," Geofluids, vol. 2019, Article ID 5274327, 14 pages, 2019.

[43] K. Zhang, Y. Song, S. Jiang et al., "Mechanism analysis of organic matter enrichment in different sedimentary backgrounds: a case study of the Lower Cambrian and the Upper Ordovician-Lower Silurian, in Yangtze region," Marine and Petroleum Geology, vol. 99, no. 2019, pp. 488-497, 2019.

[44] S. M. Rimmer, "Geochemical paleoredox indicators in Devonian-Mississippian black shales, Central Appalachian Basin (USA)," Chemical Geology, vol. 206, no. 3-4, pp. 373391, 2004.

[45] R. Raiswell and R. A. Berner, "Pyrite and organic matter in Phanerozoic normal marine shales," Geochimica et Cosmochimica Acta, vol. 50, no. 9, pp. 1967-1976, 1986.

[46] R. Raiswell, F. Buckley, and R. A. Bern, "Degree of pyritization of iron as a paleoenvironmental indicator of bottom-water oxygenation," SEPM Journal of Sedimentary Research, vol. 58, no. 5, pp. 812-819, 1988.

[47] H. D. Rowe, R. G. Loucks, S. C. Ruppel, and S. M. Rimmer, "Mississippian Barnett Formation, Fort Worth Basin, Texas: Bulk geochemical inferences and Mo-TOC constraints on the severity of hydrographic restriction," Chemical Geology, vol. 257, no. 1-2, pp. 16-25, 2008.

[48] S. D. Schoepfer, J. Shen, H. Wei, R. V. Tyson, E. Ingall, and T. J. Algeo, "Total organic carbon, organic phosphorus, and biogenic barium fluxes as proxies for paleomarine productivity," Earth Science Reviews, vol. 149, pp. 23-52, 2015.

[49] S. Rimmer, J. Thompson, S. Goodnight, and T. Robl, "Multiple controls on the preservation of organic matter in DevonianMississippian marine black shales: geochemical and petrographic evidence," Palaeo-geography Palaeoclimatology Palaeoecology, vol. 215, no. 1-2, pp. 125-154, 2004.

[50] E. Suess, "Particulate organic carbon flux in the oceans-surface productivity and oxygen utilization," Nature, vol. 288, no. 5788, pp. 260-263, 1980.

[51] D. Yan, J. Wang, and Z. Wang, "Biogenetic barium distribution from the Upper Ordovician to Lower Silurian in the Yangtze area and its significance to paleoproductivity," Journal of Xi'an Shiyou University: Natural Science Edition, vol. 24, no. 4, pp. 16-19, 2009.

[52] J. Dymond, R. Collier, J. Mcmanus, S. Honjo, and S. Manganini, "Can the aluminum and titanium contents of 
ocean sediments be used to determine the paleoproductivity of the oceans?," Paleoceanography, vol. 12, no. 4, pp. 586-593, 1997.

[53] M. L. Keith and J. N. Weber, "Carbon and oxygen isotopic composition of selected limestones and fossils," Geochimica Et Cosmochimica Acta, vol. 28, no. 10-11, pp. 1787-1816, 1964.

[54] G. Sun, B. Chen, Y. Zheng, M. Xie, W. Xia, and J. Shi, "Diagenesis and sedimentary environment of Miocene in Lenghu $\mathrm{V}$ tectonic belt,” Natural Gas Geoscience, vol. 26, no. 4, pp. 679-688, 2015.

[55] T. W. Hearing, T. H. P. Harvey, M. Williams et al., "An early Cambrian greenhouse climate," Science Advances, vol. 4, no. 5, article eaar5690, 2018.

[56] Y. Zhang, Z. He, B. Gao, and Z. Liu, "Sedimentary environment of the Lower Cambrian organic-rich shale and its influence on organic content in the Upper Yangtze," Petroleum Geology \& Experiment, vol. 39, no. 2, pp. 154-161, 2017.

[57] C.-W. Ke, Y.-H. Xu, X.-C. Chang, and W.-B. Liu, "Composition and distribution of NSO compounds in two different shales at the early maturity stage characterized by negative ion electrospray ionization coupled with Fourier transform ion cyclotron resonance mass spectrometry," Petroleum Science, vol. 15, no. 2, pp. 289-296, 2018.

[58] S. Yin, D. Lv, L. Jin, and W. Ding, "Experimental analysis and application of the effect of stress on continental shale reservoir brittleness," Journal of Natural Gas Science and Engineering, vol. 15, pp. 478-494, 2018.

[59] K. Bostrom, T. Kraemer, and S. Gratner, "Provenance and accumulation rates of opaline silica, $\mathrm{Al}, \mathrm{Ti}, \mathrm{Fe}, \mathrm{Mn}, \mathrm{Cu}, \mathrm{Ni}$ and Co in Pacific pelagic sediments," Chemical Geology, vol. 11, no. 2, pp. 123-148, 1973.

[60] R. W. Murray, M. R. Buchholtz Ten Brink, D. C. Gerlach, G. P. Russ, and D. L. Jones, "Rare earth, major, and trace elements in chert from the Franciscan complex and Monterey group, California: assessing REE sources to fine-grained marine sediments," Geochimica et Cosmochimica Acta, vol. 55, no. 7, pp. 1875-1895, 1991.

[61] J. Liu and M. Zheng, "Geochemistry of hydrothermal sedimentary silicalite," Acta Geological Sichuan, vol. 13, no. 2, pp. 110-118, 1993.

[62] J. Yang, D. Wang, J. Mao, Z. Zhang, Z. Zhang, and Z. Wang, "The petrochemical research method for silicalite and its application to the "Jingtieshan type" iron deposits," Acta Petrologica et Mineralogical, vol. 18, no. 2, pp. 108-118, 1999.

[63] Z. Liu, B. Gao, Y. Zhang, W. Du, D. Feng, and H. Nie, “Types and distribution of the shale sedimentary facies of the Lower Cambrian in Upper Yangtze area, South China," Petroleum Exploration and Development, vol. 44, no. 1, pp. 21-31, 2017.

[64] H. K. Holdaway and C. J. Clayton, "Preservation of shell microstructure in silicified brachiopods from the upper cretaceous Wilmington sands of Devon," Geological Magazine, vol. 119, no. 4, pp. 371-382, 1982.

[65] K. H. Wedepohl, "Environmental influences on the chemical composition of shales and clays," Physics and Chemistry of the Earth, vol. 8, pp. 307-333, 1971.

[66] M. Adachi, K. Yamamoto, and R. Sugisaki, "Hydrothermal chert and associated siliceous rocks from the Northern Pacific their geological significance as indication od ocean ridge activity," Sedimentary Geology, vol. 47, no. 1-2, pp. 125-148, 1986.
[67] K. Yamamoto, "Geochemical characteristics and depositional environments of cherts and associated rocks in the Franciscan and Shimanto Terranes," Sedimentary Geology, vol. 52, no. 1-2, pp. 65-108, 1987.

[68] S. M. Savin and S. Epstein, "The oxygen isotopic compositions of coarse grained sedimentary rocks and minerals," Geochimica et Cosmochimica Acta, vol. 34, no. 3, pp. 323-329, 1970.

[69] P. L. Knauth and S. Epstein, "Hydrogen and oxygen isotope ratios in nodular and bedded cherts," Geochimica et Cosmochimica Acta, vol. 40, no. 9, pp. 1095-1108, 1976.

[70] Y. Huang, Z. Jiang, K. Zhang et al., "Effect of hydrothermal activity on organic matter enrichment of shale: a case study of the Upper Ordovician and the Lower Silurian in the Lower Yangtze, South China," Minerals, vol. 8, no. 11, p. 495, 2018.

[71] J. Peng, J. Tian, H. Yi, and W. Xia, “The Late Precambrian hot water sedimentation of the Southeast Yangtze Plate continental margin," Acta Sedimentologica Sinica, vol. 18, no. 1, pp. 107-113, 2000.

[72] W. Zhang, L. Jiang, H. Gao, and R. Yang, "Study on sedimentary environment and origin of black siliceous rocks of the Lower Cambrian in Guizhou Province," Bulletin of Mineralogy, Petrology and Geochemistry, vol. 22, no. 2, pp. 174-178, 2003.

[73] X. Sun, J. Chen, W. Liu, S. Zhang, and D. Wang, "Hydrothermal venting on the seafloor and formation of organic-rich sediments: evidence from the Neoproterozoic Xiamaling Formation, North China," Geological Review, vol. 49, no. 6, pp. 588-595, 2003.

[74] X. Sun, J. Chen, J. Zheng, and W. Liu, “Geochemical characteristics of organic matter-rich sedimentary strata in lower Cambrian, Tarim Basin and its origins," Acta Sedimentologica Sinica, vol. 22, no. 3, pp. 548-552, 2004.

[75] W. Zhang, H. Yang, L. Xie, and Y. Yang, "Lake-bottom hydrothermal activities and their influences on the high-quality source rock development: a case from Chang 7 source rocks in Ordos Basin, China," Petroleum Exploration and Development, vol. 37, no. 4, pp. 424-429, 2010.

[76] M. Halbach, A. Koschinsky, and P. Halbach, "Report on the discovery of Gallionella ferruginea from an active hydrothermal field in the deep sea," InterRidge News, vol. 10, no. 1, pp. 18-20, 2001.

[77] M. A. McKibben, A. E. Williams, and G. E. M. Hall, "Solubility and transport of plantinum-group elements and Au in saline hydrothermal fluids; constraints from geothermal brine data," Economic Geology, vol. 85, no. 8, pp. 1926-1934, 1990.

[78] M. A. Korzhinsky, S. I. Tkachenko, K. I. Shmulovich, Y. A. Taran, and G. S. Steinberg, "Discovery of a pure rhenium mineral at Kudriavy volcano," Nature, vol. 369, no. 6475, pp. 51-52, 1994.

[79] K. Liu, Q. Feng, J. Shen, M. Khan, and N. J. Planavsky, "Increased productivity as a primary driver of marine anoxia in the Lower Cambrian," Palaeogeography, Palaeoclimatology, Palaeoecology, vol. 491, pp. 1-9, 2018. 